\title{
STRESSORS AND COPING STRATEGIES ON DISTANCE LEARNING AMONG EDUCATION STUDENTS
}

\author{
Sanny M. Daraman ${ }^{1}$, Dr. Ronald S. Decano ${ }^{2}$ \\ ${ }^{I}$ Graduate Student, Doctor of Philosophy in Educational Management, Davao del Norte State College \\ ${ }^{2}$ Dean, Institute of Advanced Studies, Davao del Norte State College
}

Article DOI: https://doi.org/10.36713/epra8848

DOI No: 10.36713/epra8848

\begin{abstract}
The impact of the worldwide pandemic can drive the school to work and apply various procedures in actualizing educational programs in the class. The Coronavirus pandemic may demolish existing emotional well-being issues and lead to more cases among youngsters and youths in light of the interesting mix of the general wellbeing emergency, social confinement, and financial downturn," (Terada, 2020). This study is designed to identify and investigate the causes of stress and coping strategies adopted among distance education students at the College of Teacher Education in Kolehiyo ng Pantukan. The respondents of this study were the 159 education students enrolled in AY 2020-2021 second semester. The descriptive correlational method and quantitative research were chosen for the reason that it was correlational in nature since it was determined the significant relationship between the stressors and coping strategies. The result shows that there was no significant difference in the perceptions of the respondents on the level of stress among education students as to gender and marital status. The result also shows that there is a significant relationship between the stressors and coping strategies used among education students.
\end{abstract}

KEYWORDS- Stressors, Coping Strategies, Distance Learning

\section{INTRODUCTION}

Universally, the conventional advanced education conveyance framework, which has a classroom setting with students and speakers, has been tested by developments in instructive conveyance systems (Soliman, 2014). The Coronavirus pandemic may demolish existing emotional well-being issues and lead to more cases among youngsters and youths in light of the interesting mix of the general wellbeing emergency, social confinement, and financial downturn," (Terada, 2020). Distance learning is generally characterized as any instructive or learning system in which the guide and the understudy are isolated topographically.

There is no collaboration between students. Distance schooling, otherwise called distance learning, or circulated learning, or far-off training, has now existed for a very long time. In the study of Kwaah 2017, distance education has come to complement the efforts of increasing access to tertiary education in Ghana. However, the study has revealed that high academic work, high frequency of examinations, financial and family problems, combined with other social responsibilities, are the major causes of stress for distance education students.

Due to the interplay of factors, the mental health issues students experience during distance learning, said one of the country's top psychiatrists, who added that such issues cannot be solely attributed to the difficulties of the overhauled education system. Dr. Rifareal of the Philippine Psychiatric Association said that it is a very complex issue or concern. These factors, we need to look at them as interplay in biological, psychological, social, and sometimes spiritual terms, "(Magsambol 2020).

Ferlazo, 2020 in his study showed high to moderate levels of stress among students during the COVID-19 outbreak. According to him, most likely due to the mandatory curfew and distance learning, female and university 
students showed a higher level of stress. The recommended way to improve stress and coping strategies is to attend online stress management programs as well as prevent further psychological consequences. Further investigations are important to lead longitudinal evaluations of mental issues, like sadness and nervousness, to deliver proof-based emotional well-being mediations during emergencies.

Online learning is stressful and irritating for students, as experienced by one student. They feel like they are not learning anything and just getting assignments back to back. The only thing they like about this is that it can be home and they can choose when they want to do the work. They don't like the fact that they are not learning anything. They just watch YouTube videos and try to figure out if what they are doing is correct.

In the future, they may choose not to do online learning because they generally hate it and it adds more stress. Students feel more anxiety in the distance learning approach because, due to distance, they are unable to discuss or share problems with instructors on a daily basis. Because the instructor is not physically there during asynchronous learning (independent learning), they may not be able to assist or help the student when they need it the most. This means the student may need to wait for the next synchronous learning period to get support or will have to reach out to the teacher via email or other communication channels. A lot of the learning used by students in discussions and groups to work through materials is peer-based. Teaching others, clarifying ideas, responding to questions, and safeguarding positions are, on the whole, phenomenal approaches to mastering and fostering basic reasoning abilities. While these are yet conceivable in distance learning, they don't have a similar social effect as cooperating face to face (Ajmal and Ahmad, 2019).

The impact of the worldwide pandemic can lead the school to work and apply various procedures in actualizing the educational program in the class. Schools are applying various methods of learning modalities to guarantee giving quality instruction. This study will be designed to identify and investigate the causes of stress and coping strategies adopted among distance education students at the College of Teacher Education in Kolehiyo ng Pantukan.

Furthermore, the study explores the coping mechanisms the students use to reduce stress in the midst of the many problems they face in their academic pursuit of the education students in Kolehiyo ng Pantukan. The following hypotheses are tested to test the level of significance, a) there is no significant difference in the perceptions of the respondents on the level of stress among education students as to gender and marital status, and b) there is no significant relationship between the stressors and coping strategies used among education students.

\section{Research Design}

\section{METHODOLOGY}

This research employed a descriptive correlation method of research, using a questionnaire as the main instrument in gathering data to determine the level of the stressor and coping strategies of education students in Kolehiyo ng Pantukan.

\section{Research Respondents}

The respondents of the study are all the education students in Kolehiyo ng Pantukan enrolled in the academic school year 2020-2021. This study will be using a survey questionnaire. The first part is the personal data where the name, gender, and marital status will be asked. The second and the third part of the questionnaire was lifted from the study of Christopher Yaw Kwaah and Gabriel Essilfie, 2017 entitled Stress and Coping Strategies among Distance Education students at the University of Cape Coast, Ghana.

\section{Research Instruments}

The five-point Likert Scale with assigned limits and corresponding descriptive equivalents were used to quantify the stressors and coping strategies associated with distance learning among students. This research was personally administered by me via a questionnaire online via a Google form.

\section{Data Analysis}

The responses will be tallied, tabulated, analyzed, and interpreted personally. a) Frequency or percent is used to determine the percentage distribution for the demographic profile of education students in terms of gender and marital status; b) mean is used to quantify the level of stressors and coping strategies used by education students, and c) ANOVA is used to quantify the responses as well as the difference in respondents' perceptions of the level of stress among education students as to gender and marital status. Lastly, Pearson product-moment correlation is used 
to quantify the responses along with the relationship between the stressors and coping strategies of education students. This study follows ethical considerations. Ethical guidelines for conducting this research are being observed. The secrecy of the participants will always be kept, protecting them from risk. Files and other information should not be left unattended.

\section{RESULT AND DISCUSSION}

The graph below presents the demographic profile of the respondents in terms of gender. There are 120 or $75.5 \%$ of the respondents are female, and the remaining 39 , or $24.5 \%$ of the total population, are male, which makes a total of 150 respondents. In terms of marital status, 120 or $75.5 \%$ of the respondents are single, 35 or $22 \%$ of the respondents are married and the remaining 4 or $2.5 \%$ of the respondents belong to single parents.

The demographic profile of the respondents in terms of Gender

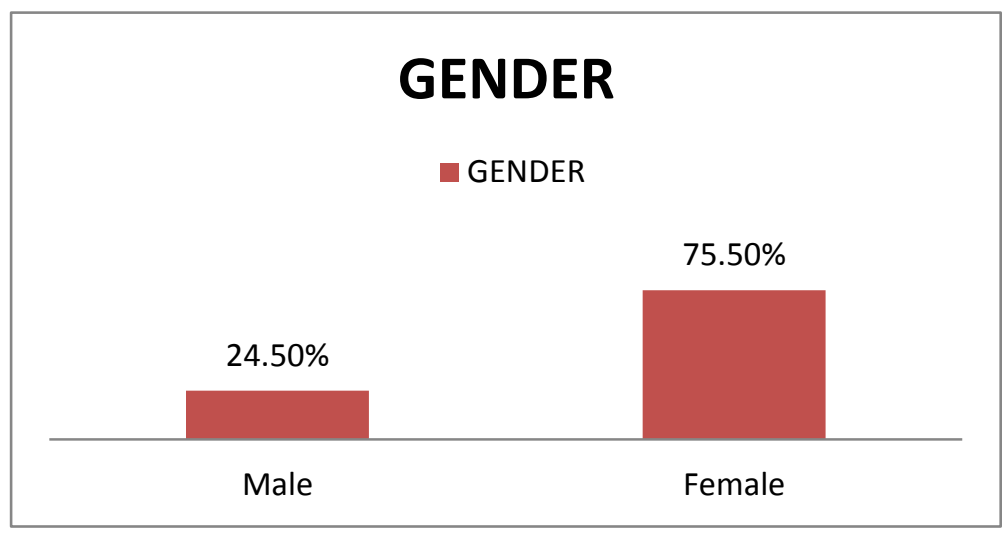

Figure 1. Demographic profile of the respondents in terms of Gender

The demographic profile of the respondents in terms of Marital Status

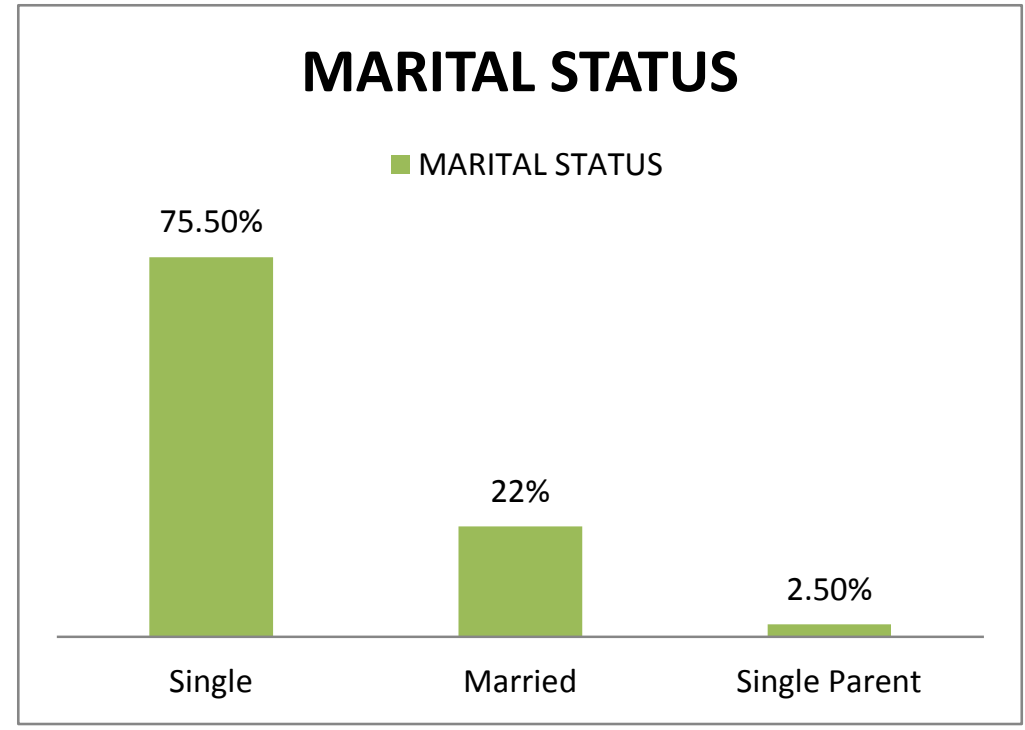

Figure 2. Demographic profile of the respondents in terms of Marital Status 
Table 1 presents the of level of the stressors of education students in Kolehiyo ng Pantukan in terms of Academic Related.

\begin{tabular}{llc}
\hline \hline Academic Related & Mean & Description \\
\hline \hline 1. High academic workload & 3.45 & Sometimes \\
2. Dissatisfaction with lectures/face-to-face & 2.77 & Sometimes \\
3. High frequency of examinations & 3.26 & Sometimes \\
4. Poor performance in examinations & 2.96 & Sometimes \\
5. Lack of learning materials & 3.07 & Sometimes \\
6. Difficulty reading and understanding modules & 2.79 & Sometimes \\
\hline \hline OVERALL MEAN & $\mathbf{3 . 0 5}$ & Sometimes
\end{tabular}

The table above depicts the level of stress experienced by education students at Kolehiyo ng Pnatukan. The stressors in terms of "Academic Related" got the total mean of 3.05 with a descriptive equivalent of Sometimes. Item number 1, which is "High Academic Workload," got the highest rank with a mean of 3.45 with a descriptive equivalent of "Sometimes." Item 3 "High frequency of examinations", item 5 "Lack of learning materials", item 4 "Poor performance in examinations" and item 6 "Difficulty reading and understanding modules" got the mean of 3.26, 3.07, 2.96, and 2.79 respectively, with a descriptive equivalent of Sometimes. Item 2 "Dissatisfaction with lectures/face-to-face" got the lowest rank with a mean of 2.77 , described as "sometimes."

Table 2 presents the of level of the stressors of education students in Kolehiyo ng Pantukan in terms of Psychosocial Related.

\begin{tabular}{llc}
\hline \hline Psychosocial Related & Mean & Description \\
\hline \hline 1. Inability to manage time & 3.38 & Sometimes \\
2. Inability to concentrate during lectures & 3.18 & Sometimes \\
3. Anxiety about my performance in exams & 3.19 & Sometimes \\
4. High parental expectations & 3.15 & Sometimes \\
5. Worries about future & 3.72 & Often \\
6. Loneliness & 3.23 & Sometimes \\
7. Financial problems & 3.92 & often \\
8. Family/marriage problems & 2.79 & Sometimes \\
\hline \hline OVERALL MEAN & $\mathbf{3 . 3 2}$ & Sometimes
\end{tabular}

The table above depicts the level of stress experienced by education students at Kolehiyo ng Pantukan. The stressors in terms of "Psychosocial Related" got the total mean of 3.32 with a descriptive equivalent of Sometimes. First in the rank is item 7, "Financial Problems", reaped with a mean of 3.92 and followed by item 6, "Worries about the Future," with a mean of 3.72 , which both have a descriptive equivalent of "often." Item 1 "Inability to manage 
time", Item 6 "Loneliness", items 3 "Anxiety about my performance in exams", items 2 "Inability to concentrate during lectures" and item 4 "High parental expectations" have a mean of 3.38, 3.23, 3.19, 3.18, and 3.15 respectively, which both have a descriptive equivalent of Sometimes. Item 8, "Family/marriage problems, " got the lowest rank with a descriptive equivalent of "sometimes."

Financial stress has been ranked as one of the top five stressors for college students (Britt, Mendiola, Schink, Tibbetts, \& Jones, 2016) and has been linked with increased anxiety and depression as well as decreased academic performance among college students (Archuleta et al., 2013). P. J. Jones et al. (2018) found that financial stress was significantly related to anxiety and accounted for the most unique variance in anxiety after academic distress.

Table 3 presents the of level of the stressors of education students in Kolehiyo ng Pantukan in terms of Health Related.

\begin{tabular}{lll}
\hline \hline Health Related & Mean & Description \\
\hline \hline & & \\
1. Lack of healthy diet/irregular eating habit & 3.27 & Sometimes \\
2. Sleep problems & 3.46 & Sometimes \\
3. Illness/ health problems & 3.46 & Sometimes \\
\hline \hline OVERALL MEAN & $\mathbf{3 . 3 9}$ & Sometimes \\
\hline \hline
\end{tabular}

Table 3 shows the level of stressors of education students in Kolehiyo ng Pantukan in terms of "Health-Related" with a total mean of 3.39 with a descriptive equivalent of Sometimes. Item 2 "Sleep problems" and item 3 "Illness/health problems" both got the highest rank with a mean of 3.46 and a descriptive equivalent of "sometimes." Item 1, "Lack of healthy diet/irregular eating habits", got the lowest rank with an e mean of 3.27 and a descriptive equivalent of "Sometimes".

Sleep problems and sleep disorders severely impair university students' academic success. In a study conducted by Buboltz et al, 31\% of all students suffered from morning tiredness (Bulbotz WC 2001). In another study, poor sleepers reported reduced daytime functioning (Alapin I, Fichten CS, 2000). Gaultney (2010) found that shorter sleep duration and an irregular sleep-wake schedule were significantly associated with a lower GPA.J.F.A clinical review provided evidence that sleep problems correlated with impeded learning, especially poorer declarative and procedural learning, neurocognitive performance, and academic success (Curcio G, Ferrara M, 2006).

Table 4 presents the Summary of level of the stressors of education students in Kolehiyo ng Pantukan.

\begin{tabular}{lcc}
\hline \hline Summary & Mean & Description \\
\hline \hline & & Sometimes \\
1. Academic Related & 3.05 & Sometimes \\
2. Psychosocial Related & 3.32 & Sometimes \\
3. Health Related & 3.39 & Sometimes \\
\hline \hline OVERALL MEAN & $\mathbf{3 . 2 6}$ & S
\end{tabular}

Table 4 summarizes the level of stress experienced by education students at Kolehiyo ng Pantukan. The overall mean of the level of the stressors is 3.26, with a descriptive equivalent of "sometimes." Based on the gathered data, "Health-Related" got the highest mean of 3.39, followed by "Psychosocial Related" with a total mean of 3.39, and lastly, "Academic Related" with a total mean of 3.05. All have a descriptive equivalent of "sometimes, "which means that the item embodied is observed sometimes.

Stress also hinders learning by limiting senses, reasoning, and memory capacity during performance, resulting in higher stress levels during subsequent performance events (Sapolsky, 1998).During patient contacts, the failure to think or remember concepts, procedures, or methods might endanger lives. Stress weakens the immune system, making people more susceptible to disease. According to research, stress hormone levels can predict 
relationship issues and chronic disease. Reducing stress could avoid colds, flu, and mild depressive symptoms, which complicate student relationships and achievements (Glaser, Robles, Malarkey, Sheridan \& Kiecolt-Glaser, 2004).

Table 5 presents the Summary of level of the Coping Strategies used of education students in Kolehiyo ng Pantukan.

\begin{tabular}{|c|c|c|}
\hline Coping strategies by the student on distance learning & Mean & Description \\
\hline $\begin{array}{l}\text { 1. Active coping: Doing something about the situation, taking action to } \\
\text { negate stressor }\end{array}$ & 3.55 & Often \\
\hline $\begin{array}{l}\text { 2. Positive reframing: Seeing something good in what is happening, } \\
\text { learning from experience }\end{array}$ & 3.87 & Often \\
\hline $\begin{array}{l}\text { 3. Alcohol/tobacco/substance abuse: Using tobacco/alcohol/drug to fell } \\
\text { better }\end{array}$ & 1.67 & Rarely \\
\hline 4. Humor: Making fun of the situation & 2.98 & Sometimes \\
\hline $\begin{array}{l}\text { 5. Given up coping: Giving up the attempt to do anything about the } \\
\text { situation }\end{array}$ & 2.74 & Sometimes \\
\hline $\begin{array}{l}\text { 6. Emotional support: Getting emotional support/advice from friends and } \\
\text { family }\end{array}$ & 3.62 & Often \\
\hline 7. Instrumental support: Getting help and advice from lectures or tutors & 3.19 & Sometimes \\
\hline $\begin{array}{l}\text { 8. Self-distraction: Doing something to take my mind off the situation } \\
\text { such as watching TV, movies, shopping, listening to music }\end{array}$ & 3.42 & Sometimes \\
\hline 9. Religion: Praying/meditating & 4.18 & Often \\
\hline 10. Venting Expressing negative feelings: showing anger at things/people & 2.85 & Sometimes \\
\hline 11. Acceptance: Learning to live with the situation, accepting it & 3.93 & Often \\
\hline 12. Denial: Refusing to believe it happened, not accepting the situation & 2.69 & Sometimes \\
\hline OVERALL MEAN & 3.23 & Sometimes \\
\hline
\end{tabular}

The overall mean of the level of the coping strategies used by the education students is 3.23 , with a descriptive equivalent of sometimes. This means that the item embodied is observed sometimes. Based on the gathered data, the item "Religion (Praying and meditating)" got the highest mean of 4.18 with a descriptive equivalent of Often. The second up to the fifth rank is the items "Acceptance (Learning to live with the situation, accepting it)", followed by "Positive reframing (Seeing something good in what is happening, learning from experience)," "Emotional support" and "Active coping" got a mean of 3.93, 3.87, 3.62, and 3.55 respectively, which means that the items are observed most of the time. The sixth up to the eleventh rank is the items "Self-distraction (Doing something to take my mind off the situation such as watching TV, movies, shopping, listening to music)", "Instrumental support (Getting help and advice from lecturers or tutors)", "Humor (Making fun of the situation, Venting "Given up coping (Giving up the attempt to do anything about the situation)" and "Denial (Refusing to believe it happened, not accepting the situation")" got a mean of 3.42, 3.19, 2.98, 2.85, 2.74, and 2.69 respectively, with a descriptive equivalent of Sometimes, which means that these items are observed sometimes. In the last rank is the item "Alcohol/tobacco/substance abuse: (Using tobacco/alcohol/drugs to feel better)". It got a mean of 1.27 with a descriptive equivalent of "rarely", which means that the item is observed in a few instances.

Coping abilities assist people in tolerating, minimizing, and dealing with stressful events. Stress management can improve your physical and psychological well-being, as well as your ability to function at your best. However, not all coping mechanisms are made equal. It can be tempting to indulge in tactics that provide immediate relief but may 
cause you more trouble in the long run. It's critical to develop good coping skills that will assist you in reducing emotional suffering or removing yourself from stressful situations. It's possible that coping tactics that work for someone else won't work for you. It's critical to build your personal coping skills toolkit that you'll find handy. It may be necessary to test a range of coping mechanisms in order to determine which ones work best (Morin, 2020).

Table 6 presents the significant difference in the perception of the respondents on the level of stress among education students as to Gender

\section{GENSTRESSORS}

\begin{tabular}{llllll}
\hline \hline & Sum of Squares & $\mathrm{df}$ & Mean Square & $\mathrm{F}$ & Sig. \\
Between Groups & .000 & 1 & .000 & .000 & .990 \\
Within Groups & 55.372 & 157 & .353 & \\
\hline \hline Total & 158 & & \\
\hline \hline
\end{tabular}

The table presents the significant differences in the perception of the respondents on the level of stress among education students as to gender. The table shows that the F-critical score of stressors of education students of Kolehiyo ng Pantukan, when grouped according to gender, is 0.000 . Based on the F distribution table, the standard value for the data given the degree of freedom tested at 0.05 level of significance is 3.8415 . The critical score of 0.000 does not exceed the standard value of 3.8415 ( $\mathrm{f}=0.000$ 3.8415) and therefore means there is no significant difference observed in the level of stress of education students in Kolehiyo ng Pantukan in terms of gender. This means that they all have the same level of stressors acquired during distance learning, regardless of gender.

However, regardless of gender, there is an overall shortage in engagement in face-to-face classroom conversation (Bordia, 1997). Students are often reluctant to participate due to anxiety or shyness, lack of preparation for class, and the classroom dynamic caused by differences in status. In contrast, many studies of asynchronous online course discussions have indicated that these discussions led to increased student participation.

Table 7 presents the significant difference in the perception of the respondents on the level of stress among education students as to Marital Status

\begin{tabular}{llllll}
\hline \hline GENSTRESSORS & & & & \\
& Sum of Squares & $\mathrm{df}$ & Mean Square & $\mathrm{F}$ & Sig. \\
& & & & & \\
& & & & \\
Between Groups & 1.870 & 2 & .935 & & \\
Within Groups & 53.502 & 156 & .343 & & \\
\hline \hline Total & 55.372 & 158 & & &
\end{tabular}

The table presents the significant difference in the perception of the respondents on the level of stress among education students as to marital status. The table above shows that the F-critical score of stressors of education students of Kolehiyo ng Pantukan, when grouped according to marital status, is 2.727. Based on the F distribution table, the standard value for the data given the degree of freedom tested at 0.05 level of significance is 3.8415 . The critical score of 2.727 does not exceed the standard value of $3.8415(\mathrm{f}=2.727$ 3.8415), which means there is no significant difference observed in the level of stress of education students in Kolehiyo ng Pantukan in terms of marital status. This means that regardless of their status, they have the same level of stressors acquired through distance learning. 
In the study of Ta et.al (2017), the current study compared perceived stress among married and single individuals across a variety of life domains in order to understand (1) the relationship between marital status and psychosocial mechanisms of stress and (2) the degree to which stress experienced in different domains is associated with other health problems (i.e., anxiety). Marital status was a significant predictor of perceived stress: singlehood was positively correlated with perceived stress, specifically the stresses associated with social commitments, loneliness, and the economy/money. These domain-specific stressors also mediated the relationship between marital status and anxiety. According to the findings, marital status can lead to different exposures to stressors and risks for mental health problems. They found that married status has significant implications for social behavior, health, and wellbeing and that the impacts of marital status on stress should be researched further in order to prevent poor health outcomes for the expanding demographic group of singles in the demographic group

Table 8 presents the significant relationship between the stressors and coping strategies among education students.

\begin{tabular}{llll}
\hline \hline & & STRESSORS & COPSTRAT \\
\hline \hline \multirow{2}{*}{ STRESSORS } & Pearson Correlation & 1 & $.419^{* *}$ \\
& Sig. (2-tailed) & & .000 \\
& $\mathrm{~N}$ & 159 & 159 \\
\multirow{2}{*}{ COPSTRAT } & Pearson Correlation & $.419^{* *}$ & 1 \\
& Sig. (2-tailed) & .000 & \\
\hline \hline & $\mathrm{N}$ & 159 & 159 \\
\hline \hline
\end{tabular}

**. Correlation is significant at the 0.01 level (2-tailed).

Table 8 shows the relationship between the level of stressors and coping strategies among education students in Kolehiyo ng Pantukan. Based on the gathered data, the result indicates that $r=0.419$, which shows a positive correlation between the two variables. The result shows that the p-value is 0.000 , which is less than the level of significance of the set alpha of 0.05 , which means that the hypothesis is rejected. This means that there is a significant relationship between stressors and coping strategies among education students in Kolehiyo ng Pantukan. Elizabeth Scott, 2020, affirmed in the annual Stress in America survey that most Americans of all ages are stressed, and a significant proportion feel their coping abilities are inadequate. Furthermore, many claim that stress is having a negative impact on their physical and emotional wellbeing. People are exposed to a wide range of stressors, and they must discover efficient ways to manage stress in their daily lives. From this widely accepted transactional approach, coping would come to be defined by cognitive and behavioral efforts employed in response to external or internal demands that the individual deems to be threats to their well-being.

\section{CONLCUSIONS}

\section{RESULTS AND DISCUSSIONS}

The demographic profile of the respondents in terms of gender is dominated by women, who make up $75.5 \%$ of the total population, while the remaining $24.5 \%$ are males. In terms of marital status, $75.5 \%$ are single, $22 \%$ are married, and the remaining $2.5 \%$ are single parents. Therefore, most of the respondents are female and single. It is occasionally observed that the level of stressors among education students in Kolehiyo ng Pantukan in distance learning is high. The level of coping strategies among education students in Kolehiyo ng Pantukan in distance learning is observed sometimes. This study has revealed that high academic workload, financial problems, sleep problems, and health problems are the major causes of stress among education students in Kolehiyo ng Pantukan. One of the best coping strategies used by the education students was prayer and meditation. The student used these coping strategies to relieve stress and to feel secure about all the problems they encountered or stress they encountered during this distance learning experience. This study also revealed that there is no significant difference in the perceptions of the respondents on the level of stress among education students as to gender and marital status 
and there is a significant relationship between the stressors and coping strategies used among education students. This study will help in the improvement of teaching strategies among teachers in teaching distance learning. It will assist the institution in initiating and implementing programs to help students cope with and reduce stress from distance learning.

\section{RECOMMENDATIONS}

The students may apply different coping strategies to relieve their stress. It may be in the form of regular sleep, daily exercise, listening to music, eating a balanced diet, always thinking positively, meditation, and praying. Many of the students take control of stress, but with all of these activities, responsibility will take place. Teachers should be aware of the stress of their students that they have experienced. It could be in school or at home, especially in this time of the pandemic. For this, teachers may help students by understanding how this could affect learning. It may be in the form of building students' emotional resilience that activates their level of cognition. School may offer students a wide range of students' breaks for practicing mindfulness, helpful sports therapy, and stress-relieving activities. The institution may conduct a mental health forum and provide counseling for all, advocate a holistic view of campus wellness, and create a task force that will engage every interested faculty member to be part of and involved in every training session conducted by the task force.

\section{ACKNOWLEDGEMENT}

Sincerest appreciation and profound gratitude are extended to the people who in their own special ways have made this research in reality. To Dr. Ronald Decano, the researcher's adviser, for his untiring assistance and giving constructive criticisms and valuable suggestions for the improvement of the study as well as for the motivation towards the completion of this study; To Dr. Jocelyn H. Hua, DFRIEdr, the College President of Kolehiyo ng Pantukan for her unending encouragement, moral support and boosting the researcher's confidence in making this research possible. To the students of College of Teacher Education of KNP for their time and effort in answering the questionnaire heartily. In addition, to the beloved parents, siblings, nieces and nephews of the researcher for their support morally and financially which keep the torch of flame against the wind of adversities to make this work a reality. Above all to the Almighty God, for all the blessings and wisdom He bestowed to the researcher while in the process of doing this research, for being so kind and generous in providing individuals who served as instruments and lent their hands during the conduct of the study which resulted to the completion of this humble work. To all of you, THANK YOU VERY MUCH.

\section{REFERENCES}

1. Abdullah, N. A. \& Dan Mohd, S.(2011). A study of stress level among part-time students in a higher institution in Kuala Lumpur, Malaysia. Journal of Global Management, 3(1), 1-34.

2. Adam Felman, 2020, What is good health? Medical News Today retireve from https://www.medicalnewstoday.com/articles/150999

3. Ajmal and Ahmad, 2019, Exploration of Anxiety Factors among Students of Distance Learning: A Case Study of Allama Iqbal Open University Muhammad Bulletin of Education and ResearchAugust 2019, Vol. 41, No. 2 pp. 67-78 retrieve from https://files.eric.ed.gov/fulltext/EJ1229454.pdf

4. Alan J. Christensen, Patricia J. Moran, in Comprehensive Clinical Psychology, 1998 Psychological Aspects of Endstage Renal Disease Health Psychology, Patient coping and adherence, registered trademark of Elsevier B.V. 2021

5. Alapin I, Fichten CS, Libman E, Creti L, Bailes S, Wright J. How is good and poor sleep in older adults and college students related to daytime sleepiness, fatigue, and ability to concentrate? J Psychosom Res. 2000;49:381-

6. AlAteeq, Deemah A., Sumayah Aljhani, DalalAlEesa, 2020, Perceived stress among students in virtual classrooms bduringthe COVID-19 outbreak in KSA Journal of Taibah University Medical Sciences retrieve from https://www.sciencedirect.com/science/article/pii/S1658361220301128

7. Al-sowygh, Z.H. 2013, Academic distress, perceived stress and coping strategies among dental students in Saudi Arabia, Saudi Dent J [Internet], 25 (3) (2013), pp. 97-105, 10.1016/j.sdentj.2013.05.002

8. American Journal Psychiatry 2006, The effect of marital status on stress in medical school retrieve https://ajp.psychiatryonline.org/doi/abs/10.1176/ajp.139.11.1490

9. Amy Morin, LCSW 2020, Healthy Coping Skills for Uncomfortable Emotions, Emotion-Focused and Problem-Focused Strategies retrieved https://www.verywellmind.com/forty-healthy-coping-skills-4586742

10. Anderson, D. M., \& Haddad, C. J. (2005, March). Gender, voice, and learning in onlinecourse environments.Journal of Asynchronous Learning Networks, 9(1), 3-14.

11. Anoushka Thakkar, 2018, Academic Stress in Students, Education, Mental Health Research Associate (Mental Health) at One Future Collective. http://onefuturecollective.org/academic-stress-in-students/ 
12. Archuleta, K. L., Dale, A., \& Spann, S. M. (2013). College students and financial distress: Exploring debt, financial satisfaction, and financial anxiety. Journal of Financial Counseling and Planning, 24(2), 50-62. Retrieved from https://files.eric.ed.gov/fulltext/EJ1043230.pdf

13. Bordia, P. (1997). Face-to-face versus computer-mediated communication: A synthesis of the experimental literature. Journal of Business Communication, 34(1), 99-118.

14. Britt, S. L., Canale, A., Fernatt, F., Stutz, K., \& Tibbetts, R. (2015). Financial stress and financial counseling: Helping college students. Journal of Financial Counseling \& Planning Education, 26(2), 172-186. Retrieved from https://files.eric.ed.gov/fulltext/EJ1088924.pdf

15. Buboltz WC, Jr, Brown F, Soper B. Sleep habits and patterns of college students: a preliminary study. J Am Coll Health. 2001;50(3):131-135. [PubMed] [Google Scholar]

16. Carlos Freire, María del Mar Ferradás, Bibiana Regueiro, Susana Rodríguez, Antonio Valle, and José Carlos Núñez 2020, Coping Strategies and Self-Efficacy in University Students: A Person-Centered Approach retrieve from https://www.ncbi.nlm.nih.gov/pmc/articles/PMC7248269/

17. Carol L.Cheatham, MarinaLarkina, Patricia J.Bauer, Sheree L.Toth, DanteCicchetti 2010 Declarative memory in abused and neglected infants Chapter 7 Advances in Child Development and Behavior Volume 38, 2010, Pages 161182

18. Chen D, Zhang R, Liu K, Hou L. Knowledge discovery from posts in online health communities using unified medical language system. Int J Environ Res Public Health. (2018) 15:1291. 10.3390/ijerph15061291 [PMC free article] [PubMed] [CrossRef] [Google Scholar]

19. Cheng C. (2001). Assessing coping flexibility in real-life and laboratory settings: a multimethod approach. J. Pers. Soc. Psychol. 80 814-833. 10.1037//0022-3514.80.5.814 [PubMed] [CrossRef] [Google Scholar]

20. Cheng C., Cheung M. W. L. (2005). Cognitive processes underlying coping flexibility: differentiation and integration. J. Pers. 73 859-886. 10.1111/j.1467-6494.2005.00331.x [PubMed] [CrossRef] [Google Scholar]

21. Collins Cobuild 2021, Definition of 'academic' retrieve https://www.collinsdictionary.com/dictionary/english/academic

22. Curcio G, Ferrara M, De Gennaro L. Sleep loss, learning capacity and academic performance. Sleep Med Rev. 2006;10(5):323-337. [PubMed] [Google Scholar]

23. DB Preston 1995, Marital status, gender roles, stress, and health in the elderly DOI: 10.1080/07399339509516166 retrieve from https://pubmed.ncbi.nlm.nih.gov/7759346/

24. Dusselier, L., Dunn, B., Wang, Y., Shelley, M., \& Whalen, D. (2010). Personal, health, academic and environmental predictors of stress for residence hall students. Journal of American College Health,54(1), 15-24. doi:10.3200/JACH.54.1.15-24

25. Eisenbarth C. (2012). Coping profiles and psychological distress: a cluster analysis. N. Am. J. Psychol. $14485-496$. [Google Scholar]

26. Elizabeth Scott, 2020What Coping Strategies Can Help Manage Stress? From Meditation to Journaling, Three Highly Effective Ways to Manage Stress

27. Emma, 2020, Mental Health and Distance Learning, Blog, Distance Learning, Educational Technology, Mental Health, Online Learning, suicide, Suicide Prevention, Technology retrieved from https://learnsafe.com/mental-healthand-distance-learning/

28. Ferlazzo, Larry 2020 Student: Online Learning Is 'Stressful and Irritating' . Education Week, retrieve from https://www.edweek.org/teaching-learning/opinion-student-online-learning-is-stressful-and-irritating/2020/05

29. Foley, Logan and Dimitriu Alex 2020 , Sleep Foundation, one care Media Company, https://www.sleepfoundation.org/insomnia/stress-and-insomnia

30. Gallagher, C. T., Mehta, A. N. V, Selvan, R., Mirza, I. B., Radia, P., Bharadia, N. S., \& Hitch, G. (2014). Perceived stress levels among undergraduate pharmacy students in the UK. Currents in Pharmacy Teaching and Learning, 1-5. doi:10.1016/j.cptl.2014.02.004

31. Gaultney JF. The prevalence of sleep disorders in college students: impact on academic performance. J Am Coll Health. 2010;59(2):91-97. [PubMed] [Google Scholar]

32. Gnilka, P. B., Chang, C. Y., \& Dew, B. J. (2012). The Relationship Between Supervisee Stress, Coping Resources, the Working Alliance, and the Supervisory Working Alliance. Journal of Counseling \& Development, 90, 63-70.

33. Gormathi, Kadayam. Soofia Ahmend, J. S. (2013). Causes of stress andcoping strategies adopted by undergraduate health professions students in a university in the United Arab Emirates. Brief Communication, 13(August), 437-441.

34. Gunther Eysenbach, Guy Fagherazzi, and John Torous, 2020. Effects of COVID-19 on College Students' Mental Health in the United States: Interview Survey Study retrieved https://www.ncbi.nlm.nih.gov/pmc/articles/PMC7473764/

35. Heather Stringer, 2020 Zoom school's mental health toll on kids. Academic and social development are likely to slip during online learning for many students. Retrieve https://www.apa.org/news/apa/2020/10/online-learning-mentalhealth

36. Huckins J, DaSilva A, Wang W, Hedlund E, Rogers C, Nepal S, Wu J, Obuchi M, Murphy E, Meyer M, Wagner D, Holtzheimer P, Campbell A. Mental Health and Behavior of College Students During the Early Phases of the COVID- 
19 Pandemic: Longitudinal Smartphone and Ecological Momentary Assessment Study, J Med Internet Res 2020;22(6):e20185, URL: https://www.jmir.org/2020/6/e20185, DOI: 10.2196/20185

37. Irawan, Andi, Dwisona, Dwisona, Lestari, Mardi, 2020, Psychological Impacts of Students on Online Learning During the Pandemic COVID-19 10. KONSELI Jurnal Bimbingan dan Konseling (E-Journal) 7(1):53-60 DOI: 10.24042/kons.v7i1.6389

38. Johnson, J. H., \& Sarason, I. G. (1979). Moderator variables in life stress research. In I. Sarason \& C. Spielberger (Eds.), Stress and anxiety, 6, 151-167.

39. Jones, P. J., Park, S. Y., \& Lefevor, G. T. (2018). Contemporary college student anxiety: The role of academic distress, financial stress, and support. Journal of College Counseling, 21(3), 252-264. doi:10.1002/jocc.12107

40. Kausar, R., 2010. Perceived stress, academic workloads and use of coping strategies by university students. J. Behav. Sci., 20: 31-45.Direct Link |

41. Kline SL, Liu F. The influence of comparative media use on acculturation, acculturative stress, and family relationships of Chinese international students. Int J Intercult Relat. (2005) 29:367-90. 10.1016/j.ijintrel.2005.07.001 [CrossRef] [Google Scholar]

42. Kobasa, S. C. (1979). Stressful life events, personality, and health-Inquiry into hardiness. Journal of Personality and Social Psychology, 37(1), 1-11.

43. Kobylińska D., Kusev P. (2019). Flexible emotion regulation: how situational demands and individual differences influence the effectiveness of regulatory strategies. Front. Psychol. 10:72. 10.3389/fpsyg.2019.00072 [PMC free article] [PubMed] [CrossRef] [Google Scholar]

44. Kwaah, G. Essilfie, 2017 Stress and coping strategies among distance education students at the University of Cape Coast, Ghana. Turk Online J DistEduc, 18 (3) (2017), pp. 120-134

45. Laffier J. On-line learning: why is it a source of stress for some post-secondary students? In E-Learn: World Conference on E-Learning in Corporate, Government, Healthcare, and Higher Education. 2019; pp. $306-315$. Association for the Advancement of Computing in Education (AACE).

46. Lazarus, R. S. (1966). Psychological stress and the coping process. New York, NY: McGraw-Hill.

47. Lazarus, R. S., \& Folkman, S. (1984). Stress, appraisal, and coping. New York: Springer.

48. M.R. Taylor, K.E. Agho, G.J. Stevens, B. Raphael 2008, Factors influencing psychological distress during a disease epidemic: data from Australia's first outbreak of equine influenza. BMC Publ Health, 13 (2008), pp. 1-13 retrieve from https://bmcpublichealth.biomedcentral.com/articles/10.1186/1471-2458-8-347

49. Magsambol, Bonz, 2020 Students' mental health issues during distance learning due to 'interplay of factors' - expert retrieve from https://www.rappler.com/nation/students-mental-health-concerns-distance-learning-due-interplay-factors

50. Marc D. Gellman, J. Rick Turner 2013 Psychosocial Characteristics, Encyclopedia of Behavioral Medicine 2013 Edition retrieve from https://link.springer.com/referenceworkentry/10.1007\%2F978-1-4419-1005-9_918

51. Molinary, Deane, Dupler Alice, Lungstrom 2009, The Stress of Online Learning, Encyclopedia of Distance Learning Second Edition retrieve

52. Nour Mheidly, Mohamad Fares, Jawad Fares, 2020, Coping With Stress and Burnout Associated With Telecommunication and Online Learning doi: 10.3389/fpubh.2020.574969 retrieve https://www.ncbi.nlm.nih.gov/pmc/articles/PMC7686031/

53. Othman N, Ahmad F, El Morr C, Ritvo P. Perceived impact of contextual determinants on depression, anxiety and stress: a survey with university students. Int J Ment Health Syst. 2019; 13(1): 17. https://doi.org/10.1186/s13033-0190275-x

54. Patricia M.Franklin2014 Kidney Transplantation-Principles and Practice (Seventh Edition) Chapter 40 Psychological Aspects of Kidney Transplantation and Organ Donation retrieve from https://www.sciencedirect.com/science/article/pii/B9781455740963000404

55. Perkowski, Justine, 2013 The Role Of Gender In Distance Learning: A Meta-Analytic Review Of Gender differences In Academic Performance and Self-Efficacy In Distance Learning State University Of New York At Stony Brook retrieve from: http://dx.doi.org/10.2190/ET.41.3.ehttp://baywood.com

56. Ramos, J. A. (2011). A comparison of perceived stress levels and coping styles of non-traditional graduate students in distance learning versus on-campus programs. Comtemporary Educational Technology, 2(4), 282-293.

57. Randy Basham.2018 Developing the Online Course in Stress Crises and Coping: A Low Stress Curriculum Design Model. Journalism Mass Commun. 2018; 8(1), https://doi.org/10.17265/2160-6579/2018.01.002

58. Reed, S., Lyons, R., Hendricks, D., \& Mead, A. (2011). Sources of stress among gender and classification for African American college students. College Student Journal, 45(4), 749-758.

59. Restauri N, Sheridan AD. Burnout and PTSD in the COVID-19 pandemic: intersection, impact and interventions. J Am Coll Radiol. (2020) 17:921-6. 10.1016/j.jacr.2020.05.021 [PMC free article] [PubMed] [CrossRef] [Google Scholar]

60. Sahu, P., 2020, Closure of universities due to coronavirus disease 2019 (COVID-19): impact on education and mental health of students and academic staff Cureus [Internet], 12 (4)(2020 Apr 4), Article e7541 retrieve form https://pubmed.ncbi.nlm.nih.gov/32377489 
EPRA International Journal of Environmental Economics, Commerce and Educational Management Journal DOI: 10.36713/epra0414 |ISI I.F Value: 0.815|SJIF Impact Factor (2021): 7.743 ISSN: 2348 - 814X Volume: 8 | Issue: 11 | November 2021

61. Saleh Alsulami, Zaid Al Omar, Mohammed S Binnwejim, Fahad Alhamdan, Amr Aldrees, Abdulkarim Al-bawardi, Meshary Alsohim, and Mohammed Alhabeeb 2018, Perception of academic stress among Health Science Preparatory Program students in two Saudi universities. Retrieve from https://www.ncbi.nlm.nih.gov/pmc/articles/PMC5856041/

62. Sara Lindberg 2019, Eustress: The Good Stress https://www.healthline.com/health/eustress

63. Selye, H. (1983). The concept of stress: Past, present and future. In C.L. Cooper (Ed.). Stress research: Issues for the eighties. New York: John Wiley.

64. Shamsuddin, K., Fadzil, F., Ismail, W. S. W., Shah, S. A., Omar, K., Muhammad, N. A., Jaffar, A., Ismail, A., Mahadevan, R. (2013). Correlates of depression, anxiety and stress among Malaysian university students. Asian Journal of Psychiatry, 6(4), 318-23. doi:10.1016/j.ajp.2013.01.014

65. Shuai Liu, et al.2020, Online mental health services in China during the COVID-19 outbreak , DOI:https://doi.org/10.1016/S2215-0366(20)30077-8

66. Siltanen S., Rantanen T., Portegijs E., Tourunen A., Poranen-Clark T., Eronen J., et al. (2019). Association of tenacious goal pursuit and flexible goal adjustment with out-of-home mobility among community-dwelling older people. Aging Clin. Exp. Res. 31 1249-1256.

67. Smith, G. G., Ferguson, D., \& Caris, M. (2002). Teaching over the web versus in the classroom: Differences in the instructor experience. International Journal of Instructional Media, 29(1), 61-67

68. Soliman, M. (2014). Perception of stress and coping strategies by medical students at King Saud University, Riyadh, Saudi Arabia. Journal of Taibah University Medical Sciences, 9(1), 30-35. doi:10.1016/j.jtumed.2013.09.006

69. Toda M, Ezoe S, Takeshita T. Mobile phone use and stress-coping strategies of medical students. Int J Cyber Behav Psychol Learn. (2014) 4:41-6. 10.4018/ijcbpl.2014100104 [CrossRef] [Google Scholar]

70. Vivian P. Ta, Amanda N. Gesselman, Brea L. Perry, Helen E. Fisher and Justin R. Garcia 2017 Stress of Singlehood: Marital Status, Domain-Specific Stress, and Anxiety in a National U.S. Sample retrieve https://doi.org/10.1521/jscp.2017.36.6.461

71. Walinga, Jennifer, 2014, Introduction to Psychology - 1st Canadian Edition 201416.2 Stress and Coping retrieve from https://opentextbc.ca/introductiontopsychology/chapter/15-2-stress-and-coping/

72. Wilks SE. Resilience amid academic stress: the moderating impact of social support among social work students. Adv Soc Work. 2008;9(2):106-125. [Google Scholar] 